\title{
The Paradigm of Antithesis and Harmony as the Dualism of Pattern Fundamental in Architecture of Residential Houses in Bali, Indonesia
}

\author{
I Kadek Merta Wijaya \\ Department of Architecture, Universitas Warmadewa, Bali, Indonesia
}

Received March 13, 2021; Revised May 9, 2021; Accepted June 6, 2021

\section{Cite This Paper in the following Citation Styles}

(a): [1] I Kadek Merta Wijaya, "The Paradigm of Antithesis and Harmony as the Dualism of Pattern Fundamental in Architecture of Residential Houses in Bali, Indonesia," Civil Engineering and Architecture, Vol. 9, No. 4, pp. 1110-1122, 2021. DOI: 10.13189/cea.2021.090413.

(b): I Kadek Merta Wijaya (2021). The Paradigm of Antithesis and Harmony as the Dualism of Pattern Fundamental in Architecture of Residential Houses in Bali, Indonesia. Civil Engineering and Architecture, 9(4), 1110-1122. DOI: 10.13189/cea.2021.090413.

Copyright $\bigcirc 2021$ by authors, all rights reserved. Authors agree that this article remains permanently open access under the terms of the Creative Commons Attribution License 4.0 International License

\begin{abstract}
Residential architecture in Bali consists of housing in the highlands with a linear pattern (luan-teben pattern) and lowlands with a sanga mandala pattern. The two residential ways form the building masses' configuration with natah (plaza or open space) as the building masses' binding space. The zoning system of building masses creates a dualism relationship pattern that contains Utama (high value) and nista (low value) meanings. The dualism relationship forms a building mass configuration with different building functions and characteristics. The purpose of this study is to examine the importance of the relationship between two building masses in high and lowland residential in the diametric and middle space aspects as the intermediate space or the second node of the diametrical building. The research method used in the study of the meaning of dualism was a qualitative content analysis of the perspective on; (1) space user characteristics; (2) the aspects of the function accommodated; (3) the philosophical background of the user community; and (4) the dynamics of change. The study focuses on highland settlements (Pinggan Village and Pengotan Village) and lowland settlements. This research found: (1) universal meaning based on the general conception of the direction of the sun rising and setting; (2) local purpose from the concept of respect for ancestors in the context of figures and places of origin; (3) the meaning of the antithesis in the context of hierarchy and spatial function; and (4) the meaning of harmony in the context of
\end{abstract}

mutually reinforcing relationships.

Keywords Antithesis and Harmony, Dualism Pattern, Luan-Teben Pattern, Sanga Mandala Pattern, Universal and Local Concepts

\section{Introduction}

The residential architectural layout of Balinese ethnic communities - highland and lowland residential architecture, has a linear residential and nine patterns (nine-zone residential pattern) [1]-[5]. Linear housing patterns usually occur in mountain settlements. Those are still vernacular with the same social level, uniformity of residential formation, oriented to the concept of ancestry and nature - the cosmology of dualism, namely Luan (high value) and Teben (low value). Linear housing patterns tend to form a central space in the middle of a critical area in an elongated shape. There are no boundaries or territories between family housings, so this extended pattern repeats itself from macro housing to residential cluster units. Each residence consists of three zones: the holy place zone, the residential zone, and the outer zone. This picture occurred in Pinggan and Pengotan villages [5]-[8]. Dualism pattern in the highland, namely the main building (Bale Meten or Bale Saka Roras) and 
supporting facilities (Bale Sakanem). The nine-zone residential pattern is formed based on the building mass configuration, including a building mass pattern towards the middle and influenced their respective roles and functions and the spatial hierarchy of highest value and lowest value zones. The highland settlement pattern has one orientation concept or the high value and low-value axes. In contrast, the lowland settlement has two crosses of natural and ritual axes. The natural axis is in the form of the rising and setting of the sun's direction and the ritual axis towards the mountain (generally Mount Agung) and the sea's movement.

Bali's residential architectural layout was influenced by the understanding of the ethnic community, especially cosmology knowledge. Knowledge of natural cosmology mountains and sea; sunrise and sunset - knowledge of the Balinese ethnic community respecting nature as the source of life and maintaining harmony and balance in nature. Bali's residential architecture based on the culture of living in the Balinese ethnic community, based on the concept of animism and dynamism, interprets this universe as having a soul or spirit, besides humans as God's creative soul and body. The images of animism and dynamism in Indonesian civilization as ancient belief concepts [9]-[12], emphasis on human contact with nature, resulting in a habitat pattern that is typically towards mountains or higher ground in the highland settlement. This concept developed in lowland settlements with a complicated life and incorporated natural and ritual aspects in spatial layout. Understanding the cosmology concept is born from the vernacular society's perspective on the existence of deceased ancestors. Respect for older people as a figure who protects their children, people who have died and resided in high places, and people who have death providing safety and well-being to the surviving family. The concept of belief where the person who has died is in the sky, the sky has a meaning as higher space or place, and elevated position on earth is generally a mountain or land higher from other lands [1], [4], [5], [13]-[20].

Understanding the phenomena above is a fundamental conception in shaping residential patterns in highland areas. This understanding also affects residential spatial planning in lowland areas by adding the concept of a natural axis, namely the direction of the sun's rising and setting [14], [21]. The idea of the sun and its direction of movement is the basis of philosophy in spatial planning, which is to provide a life for living things through symbols of the beginning (hope, birth) and the end (death) as a natural cycle of human life.

The background of the concept that underlies the layout of both high and lowlands has not been studied. These studies are only limited to identifying these concepts, not finding the meaning behind the layout's idea. The cosmology of vernacular living space in Indonesia has been done a lot, but fundamental studies are still minimal.
The research focuses on studying the concept of belief in ancestors or gods who reside at the top of mountains or high places as part of the vernacular spatial [7], [22]-[29]. Others study the concept of the direction of the rising and setting of the sun in the vernacular settlement [26], [30][34]. These studies generally lead to studies identifying housing and orientation patterns that have been previously defined and developed so far in vernacular settlements. The background of this spatial pattern is still being studied. The dualism pattern way is fascinating to learn because it will produce a fundamental understanding of the settlement layout of Balinese ethnic communities in the dynamics of increasingly modern housing developments. Spatial planning development due to human settlements demands a functional space and contemporary trends in society regarding residential spatial planning. The pattern cannot be avoided; what can be done is to understand the fundamentals of residential spatial planning so that the substance (core) and supporting (peripheral) elements are known.

The aspects mentioned above influence the culture of living, which is oriented to the cosmological and physical contextual aspects of land, not only occurs in Indonesia but outside Indonesia the concept of a culture of living. Sacred and profane cosmology is a dualism in spatial settlement planning. According to Ashdown that there is a paradox between sacred and secular spaces in their value orientation, the orientation of the value of the holy area is influenced by substantial (ritual) and situational (religious experience) encounters. The value of sacredness fades when the ritual meetings decrease, and space can increase sacredness while maintaining these aspects of the ritual. The sacred and profane show that space's dualism [35]. According to García \& Belmonte, the orientation of the Hellenic community settlements in the Mediterranean Iron Age was towards mountains, forests, and springs. There is dualism in the spatial orientation in Hellenic community settlements. Namely, there are two settlement orientations, namely (1) based on aspects of local wisdom; and (2) based on fundamental needs (aspects of a place to get a living, clothing, and food).[36] Another research conducted by Zhou et al. states that settlement orientation is not based on rituals but is influenced by aspects of the physical environment. Such settlements in Dong in China experience migration and adapt to their physical environment, namely Mountain, Water, Forest, and Paddy fields. Territory forms direct payments - main settlements and secondary settlements - peripheral settlements that develop and adapt to their environmental conditions [37]. From the study above, it can be concluded that there is a dualism of settlement orientation, namely, primary orientation and peripheral orientation.

The research examines the fundamental concepts of residential spatial planning for communities in the highlands and lowlands. This whole concept is the basis for people's thinking in arranging their living space based 
on historical review and the contextual environment. The method used in this study is qualitative content analysis, and the object of the study is on highland settlements (Pinggan and Pengotan Village) and lowland settlements that are in Denpasar City. The locus of different character studies was conducted based on (1) vocabulary and traditional also contemporary territories; (2) understand the spatial structure of vernacular society and modern society; (3) there are varied findings so that the results are more substantial; and (4) the character of the occupancy in each different village, which is in mountainous areas that is still having a vernacular name, while the lowland areas are contemporary. The differences in this object's character produce exciting and varied findings, so that general and interpretive conclusions become fundamental findings. Content research emphasizes the interpretation of the content presented or contained in the study object and conducts a dialogue with relevant approaches to logically account for research results.

\section{Materials and Methods}

This study uses a qualitative method of content analysis on the concepts that are the basis for Balinese community housing in the high and lowlands areas. This method emphasizes the interpretation of phenomena that occur in an empirical context and textual thoughts, both of which experience a conceptual dialogue to formulate a meaning behind these phenomena [38]-[41]. The phenomena studied are the Balinese people's residential arrangements who live in the high and lowlands and their settlements' development dynamics. The approach or paradigm used in this study is (1) historical community settlements in mountainous and lowland areas; (2) the belief system of the local community; (3) understanding of universal concepts; (4) function and user community of the building or space; and (5) residential development dynamics.

The analysis technique used in a model [42] divides the research process into two major stages: empirical and conceptual. Practical deals with phenomena related to conceptual housing and its dynamics and concepts as a synthesis stage by interpreting these findings. The steps of this research are: (1) identifying the idea of occupancy at the locus; (2) studying binary relationships in the diametrical context; (3) understanding the character of each building or space; (4) having a dialogue on general or universal understandings; and (5) formulating the meaning of dualism pattern as the basis for forming linear housing system and nine zones pattern. The technique of analyzing data is through a coding system translated as finding themes for further dialogue with universal theories - data obtained through observation and interviews in an unstructured manner to find relevant and naturalistic information. In addition to compliance, consultations are also a tool to get data in this study; the results of interviews are analyzed (coding) to formulate themes of findings.

\section{Research Result}

\subsection{Dualism Pattern in Highland Residential Architecture Spatial Layout}

The spatial pattern of highland Bali residential architecture has a linear way, uniformity of building habits, and shapes. The architectural forms influence people who do not have a social status level. The spatial way of residential architecture comes from religious and profane orientations, a fundamental local concept shaping the residential layout in the highlands. Uniformity in form as a social aspect and a local idea in cultural values affects residential spatial planning [43]-[46]. The consistency of sacred and profane dualism concepts forms a dualism pattern. Dualism pattern identical to binary diametric as an arrangement or hierarchy of two conflicting spaces in a diametric relationship [47]. The constructed space hierarchy produces a spatial zoning system, namely the holy place zone, the residential zone, and the outer zone (the outside of the yard area). The residential site comes from two building masses' configurations as mutually oriented towards the plaza. Each cluster consists of rows of shelters composed of 8 to 10 houses; without being limited by a wall (fence) for each dwelling, only the land's height distinguishes between one residence and another. There is no family relationship in the form of a "blood" relationship between one dwelling and another-the images of residential architectural layouts in Pinggan and Pengotan villages. The linear patterned housings are grouped into residential clusters, each housing in the cluster has no "blood" relationship [5], [6], [8].

One residential unit in Pinggan and Pengotan Village village has three zones: the sanggah (temple) zone, the residential zone, and the outer zone. Inside, the residential from a configuration of two building masses (Bale Saka Roras/Bale Adat and Sakanem) facing each other and oriented towards the centre space. The dualism pattern is the determined concept through an orientation towards Puncak Penulisan Temple in Pinggan Village and Pura Tuluk Biyu in Pengotan Village, which places the sacred place zone (Sanggah) in this direction as a direction or pole of holy value, which local people call the Kaja direction (spiritual path). The sacred opposition direction is lebuh (space in front of gate residential), which access the residence. There is an entrance as a sign of the binary opposition's order-the worship zone towards God and ancestors in the main direction to Bukit Penulisan Temple. Relationship means the community relationship between Pinggan Villages and Pengotan Village respects the ancestors who resided in Pura Bukit Tulisan and Pura 
Tuluk Biyu. The concept of belief in ancestors in rural communities in mountainous areas affects the concept of spatial orientation as a sacred direction [18], [19], [48], [49]. The firm past between Pinggan Village and the Puncak Penulisan Temple and the Pengotan Village community with the Tuluk Biyu Temple forms a residential spatial layout by placing a holy place or Sanggah the Puncak Penulisan Temple. The binary opposition from the direction of Kaja (sacred) is lebuh (space in front of the front yard of the house), usually as an accessible room and area for physical activities (non-spiritual). In the residential zone, there are two building masses designated for parents or girls and boys. Buildings intended for parents or girls occupy the sacred direction or the Kaja direction (the primary path) as a form of respect for parents and girls. Family members need to be protected and respected. (see figure 1 and figure 2). Dualism patterns come from the middle space existence and the sky's direction. Natah is a physical symbol where humans live, and the sky symbolizes the gods or ancestors' dwelling place. [21], [50], [51].

Patterns from another dualism are the direction of sunrise (Kangin) and sunset (Kelod). The religious order (Kangin) is towards Pura Ulun Danu Batur in Pinggan
Village and Bukit Abang in Pengotan Village, while the opposition is in the opposite direction. This direction by the placement of pelinggih (worship elements) to the ancestors oriented towards the Kangin. Ulun Danu Batur temple is a place for the Moksa (level of human perfection) of King Sri Aji Jayapangus, an ancestor or someone highly respected by the community [8]. Meanwhile, as the place of origin for Pengotan Village people, Bukit Abang is now before the Panji Sakti expedition [5]. This description shows that the main direction (sacred/Kangin) on the concept is prioritized or respected and has a historical relationship with the population concerned. Meanwhile, the opposition to this direction is more in order of physical value.

The orientation with sacred values in Pinggan and Pengotan villages forms a macro spatial layout on a residential scale. The direction of Kaja as a dualism pattern has a primary (religious) value by placing the holy places (Pura Desa and Puseh) in the order of Kaja in Pinggan Village and Pengotan Village. Opposition from this direction has a profane value occupied by elements of Pura Dalem and Setra or graves. Pura Desa and Pura Puseh are symbols of the house's soul, while Pura Dalem and graves are symbols of the house's body.

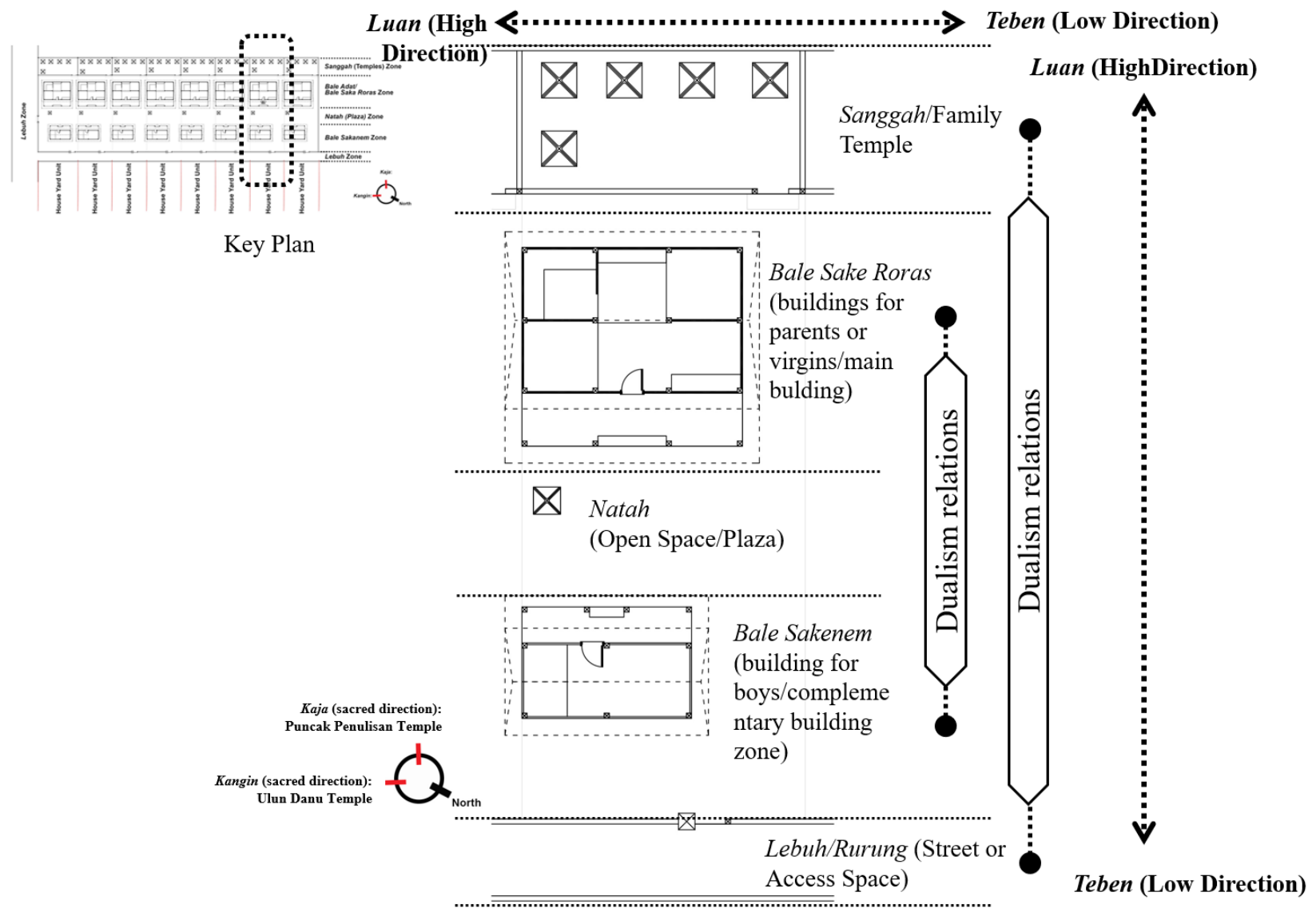

Figure 1. Dualism Pattern in Pinggan Village Residential 


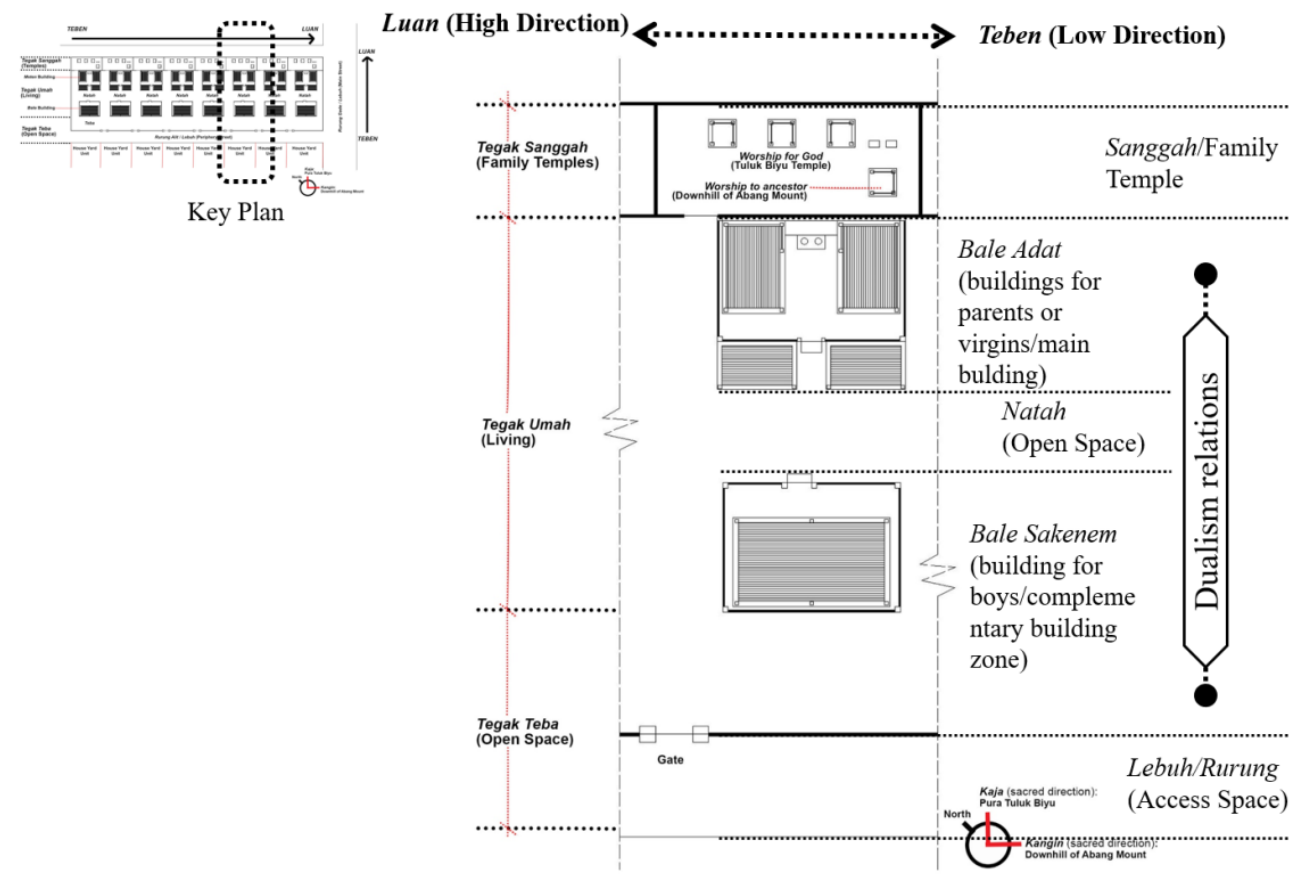

Luan (HighDirection)

Figure 2. Dualism Pattern in Pengotan Village Residential

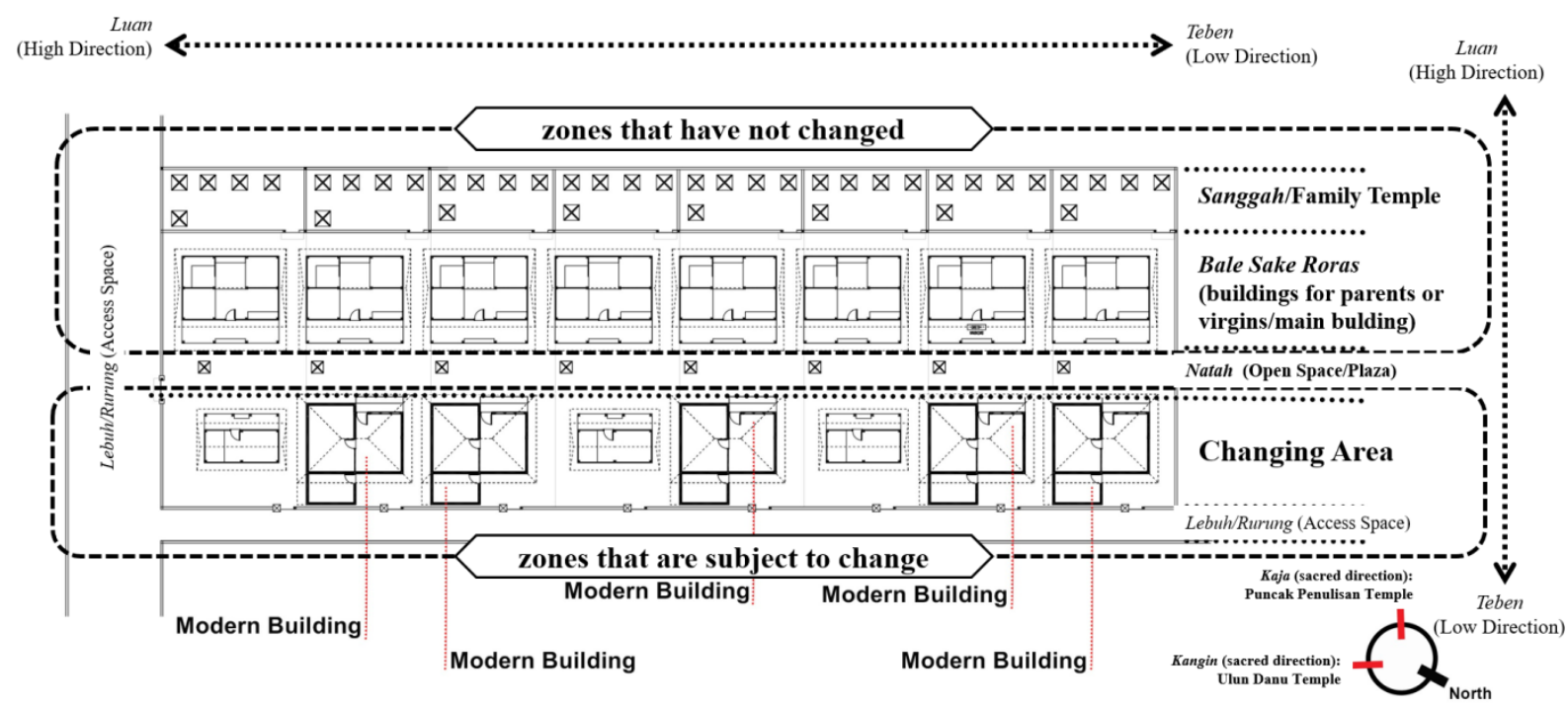

Figure 3. Zones That are Subject to Change in Pinggan Village

The dualism pattern concept influences the shape transformation of a house or building mass and its spatial structure. The direction that tends to be maintained is building mass and space that does not experience additional building abundance in the Kaja and Kangin directions. Kaja and Kangin indicate that this direction symbolizes the soul, the residential entity, and the dwelling's strength in Pinggan and Pengotan villages. The order or zone that usually undergoes a change or transformation of space and the shape of the building mass is the direction of Kelod and Kauh. Kelod and Kauh area as development new buildings in residential dwellings and toilets in the profane order. There are additional buildings with contemporary architectural styles in a secular direction on the residential scale. (see figure 3)

\subsection{Dualism Pattern in Lowland Residential Architecture Spatial Layout}

The nine zones concept affects the spatial layout of Balinese ethnic dwellings in lowland areas [14], [15], [52], [53]. The residential site zoning system divides the house yard into nine zones; each zone has a hierarchy of space, from the highest to the lowest. The designation of each order of freedom does manifest in the mass of the building and open space. The configuration of the building mass forms a pattern that has oriented toward the plaza. [21], 
[51], [52]. The plaza's existence affects the occupancy pattern in a yard towards the middle (space), the facade of the building mass facing the middle space. This concept comes from the crossing of the idea of religious orientation (Kaja and Kangin direction) and profane (Kelod and Kauh direction), which is called the natural axis and the ritual axis [27], [54]-[56]. The natural axis is interpreted as the orbital movement of the sun rising and setting, while the ritual axis is the direction of the mountains and the sea. The intersection of these two axes forms a spatial layout with a hierarchy of high value and low-value spaces. The pattern consists of (1) the holy place zone (Sanggah); (2) Bale Meten building zone; (3) the Bale Dangin building zone; (4) Bale Delod building zone; (5) Bale Dauh building zone; (6) the area of the Pelinggih Penunggun Karang (holy statue); (7) the kitchen building zone; (8) Jineng (rice storage) building zone; (9) pig pen zone; (10) Natah (open space or plaza) zone; and (11) the entrance zone or Angkul-angkul. The placement of the masses and length in a residential yard is influenced by the orientation and hierarchy of sacred (high value) and profane (low value). These holy and unholy conceptions reinforce each other and form a dualism pattern as the basis for developing the nine patterns concept. Dualism pattern is a relationship between two opposing poles but creates a harmonious and balanced relationship.

There is a dualism pattern on the ritual axis between
Bale Daja or Bale Meten (sacred direction) and Bale Delod (profane order). The two buildings are facing each other and the plaza as the binding of the two periods. The dualism consists of sacred and secular levels through an orientation direction of the house's user or occupant. The holy or central order is in the Bale Meten or Bale Daja direction, while the profane order is in the Bale Delod building. Bale Daja or Bale Meten is a building used by parents or elders in the family concerned or designated as a place for unmarried girls [50], [52], [57], [58]. Bale Daja or Bale Meten's function and user characters show that parents mean someone who needs to be respected by their existence and represent the ancestors. Unmarried girls have a meaning as a symbol that is still holy or not tarnished, and it is necessary to maintain their presence by placing them in a closed Bale Daja building. Respect for ancestors and things that have sacred values is in a divine direction and zone. It is opposite the Bale Delod, which functioned as a bedroom for the boy to maintain the house's existence. The meaning of "guarding" is marked by the semi-open Bale Delod building and as a place for men. So, the dualism pattern relationship between Bale Daja and Bale Delod has the meaning "soul" and "body"; between soul and body does not negate but strengthen. Bale Daja and Bale Delod mean that each has a role and function through spatial planning based on its characteristics. (see figure 4)

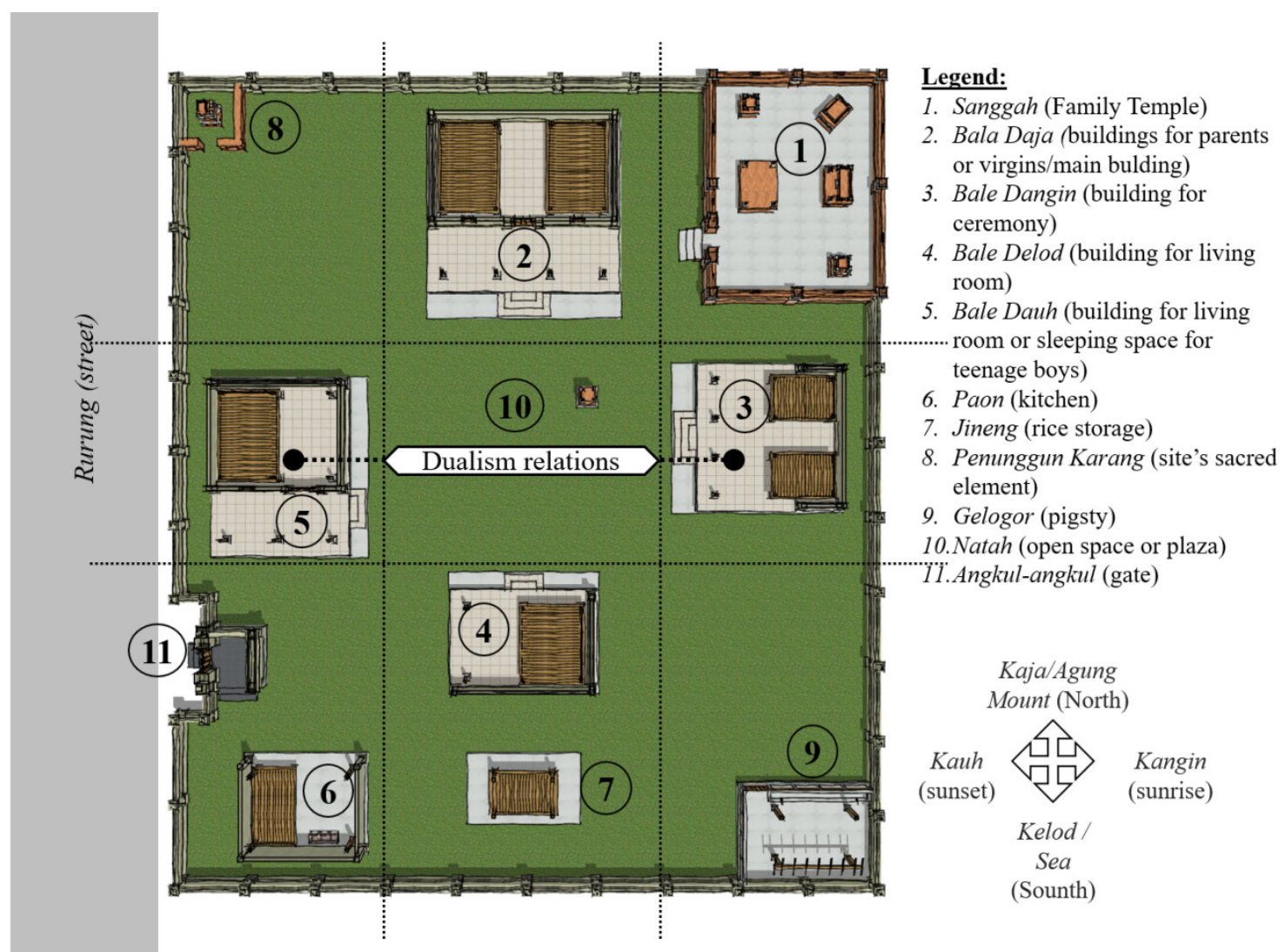

Figure 4. Dualism Pattern Relationship between Bale Daja and Bale Delod 
Another dualism is between Bale Dangin and Bale Dauh, each of which is in the high-value zone or the direction of the sun rising and nista (low value) or the direction of the sun setting. Bale Dangin functions as a building for carrying out human ceremonial activities, namely marriage, otonan (Balinese birthday), and funerals This building's orientation is in the rising sun's direction and the building's path facing the plaza. The order of the sun rising is a symbol of new hope or new life. A person's death is not the end of life but is the beginning of new birth, marriage as the beginning of running a married life, and the otonan (Balinese version of birthday) ceremony as a prayer for the better. Hope and a new life through religious traditions at Bale Dangin are placed in the high-value zone as the beginning of life. The Bale Dauh building functions as a living room or a boy's residence. Bale Dauh is used to receive guests during traditional ceremonies, orientation towards the middle space, and rising sun. Bale Dauh aims to direct the guests' eyes to watch the manusa yadnya ceremony held at Bale Dangin. So, it can be concluded that the dualism pattern Bale Dangin and Bale Dauh have a meaning as a new future hope direction and neutralize negative influences on the sun set's guide (kauh). The relationship between these two directions or poles has a significant role. It strengthens each other to achieve a level of balance in the occupancy of Balinese ethnic houses. (see figure 5)

The shrine building or the Sanggah and the kitchen building or the Paon are dualism pattern pairs formed diagonally. The shrine zone is in the highest value zone, and the Paon or the kitchen is in the Nista Ning Nista zone (the lowest value). Their existence in a nine patterned spatial structure plays a significant role and strengthens one another. Building a holy place is a symbol of holiness associated with divinity, and people who enter the room must meet the sacred space's requirements. Manifestations, in the form of freedom, mark sacred spaces as religious identities; this manifestation is in the form of a hierophant [56], [59]-[62]. It is different from the kitchen building or the paon building used as a place for cooking, but symbolically has a meaning as a smelter or destroyer of opposing forces. The kitchen has a substance as a neutralizer of opposing forces that enter the yard and object. The dualism relationship between the two elements has a significant role in creating and maintaining an intangible balance in the yard. (see figure 6)

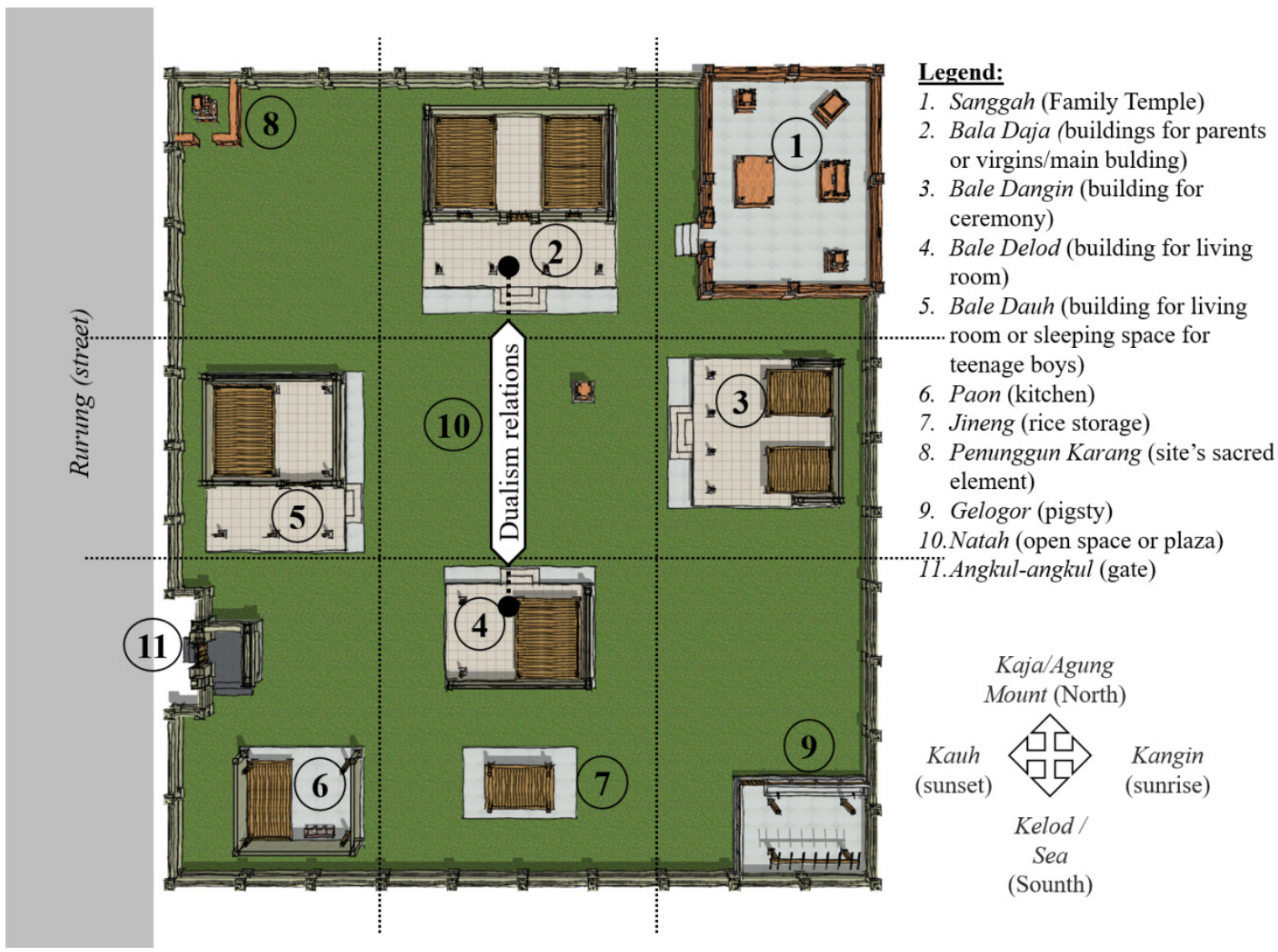

Figure 5. Dualism Pattern Relationship between Bale Dangin and Bale Dauh 


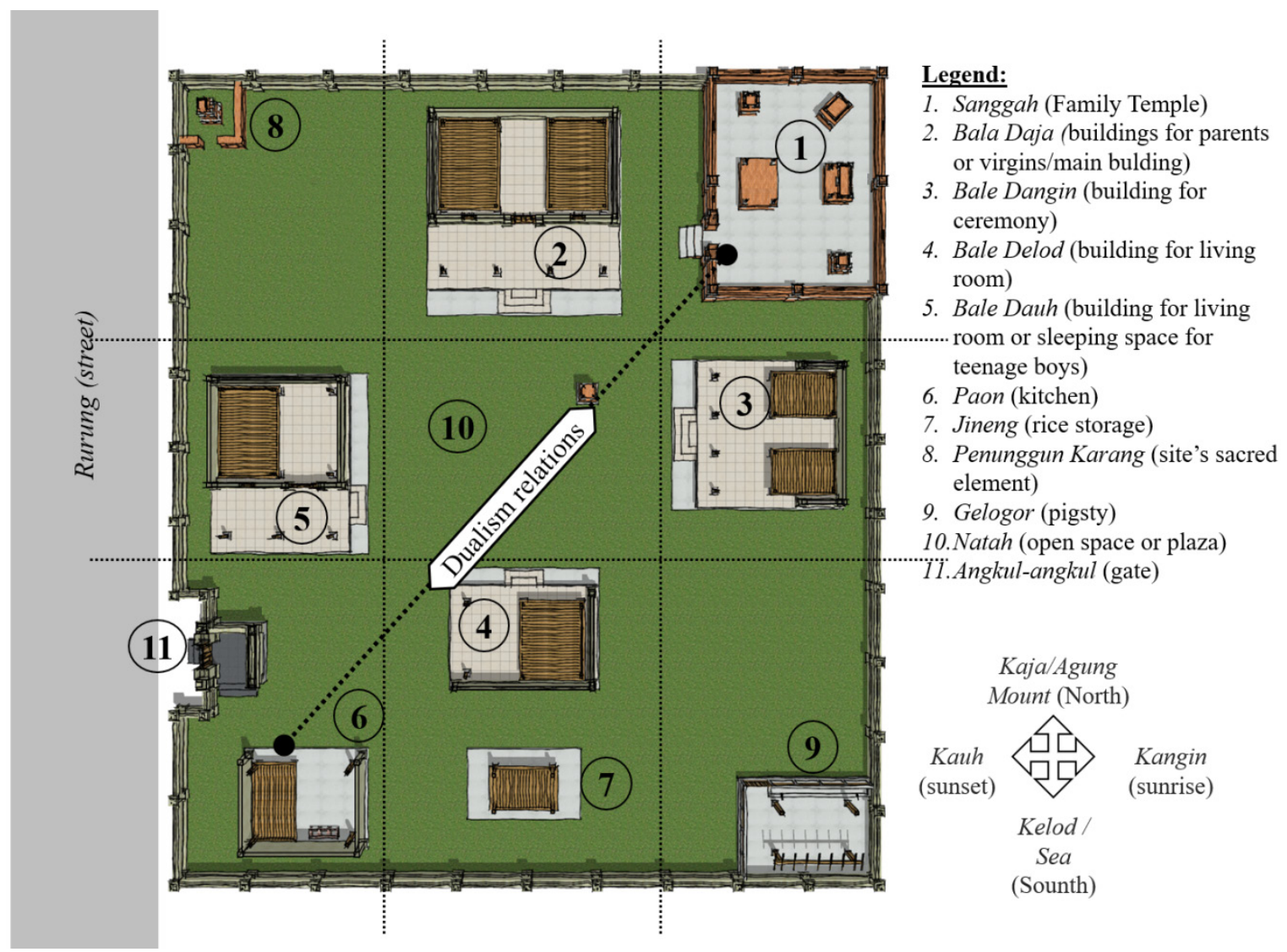

Figure 6. Dualism Pattern Relationship between Sanggah and Paon

Natah has an essential role in safety during disaster mitigation; when an earthquake occurs, as an open space, it becomes a destination for an escape from earthquakes [21]. However, in rituals, the area used mecaru ceremonies - a ceremony to neutralize natural forces under the human realm or the invisible world in the human realm. The mecaru symbolic and valuable as a space for balance, namely, harmonization between tangible and intangible areas and areas for disaster mitigation. Balanced space, the plaza becomes a knot space in a patterned layout, with its centre in the middle of the yard. The opposition from the middle area is the sky, which symbolically is the place where the gods reside who give gifts to earthly creatures. They receive assistance from heaven (the gods); space must first be neutralized through ceremonial activities to receive holy revelations in a clean container. There is an understanding of the sky as the space of the gods. The dualism pattern context between akasa (sky) and pertiwi (earth/natah) has an inseparable relationship, both of which influence each other in maintaining symbolic balance and benefit in the nine patterned spatial layouts. Before a religious ceremony is carried out in the yard of a Balinese ethnic residence, a tradition is carried out in the middle space to clean the bhuta world (invisible power) so that revelations that are sent down from the sky or above can be adequately received without being disturbed by bhuta elements. (see figure 7).

The development of lowland residential spatial planning transforms (form and function addition) in each zoning. The occurs are due to economic growth, the increasing need for space, and the trend in the development of traditional Balinese architecture towards neo-traditional or contemporary [5]. This development is dominated by the masses of buildings in the defiled or offensive zone, while the primary or sacred site does not experience significant changes. The addition of new space functions or facilities generally occurs in these zones. Zones and building masses fixed based on their position and role are sanggah (holy place), Bale Daja, and Bale Dangin. The dualism pattern is very clearly visible from its spatial structure development; the space with the high value still retains its value. The one with the nista value undergoes a transformation based on the development of the era and space requirements. 


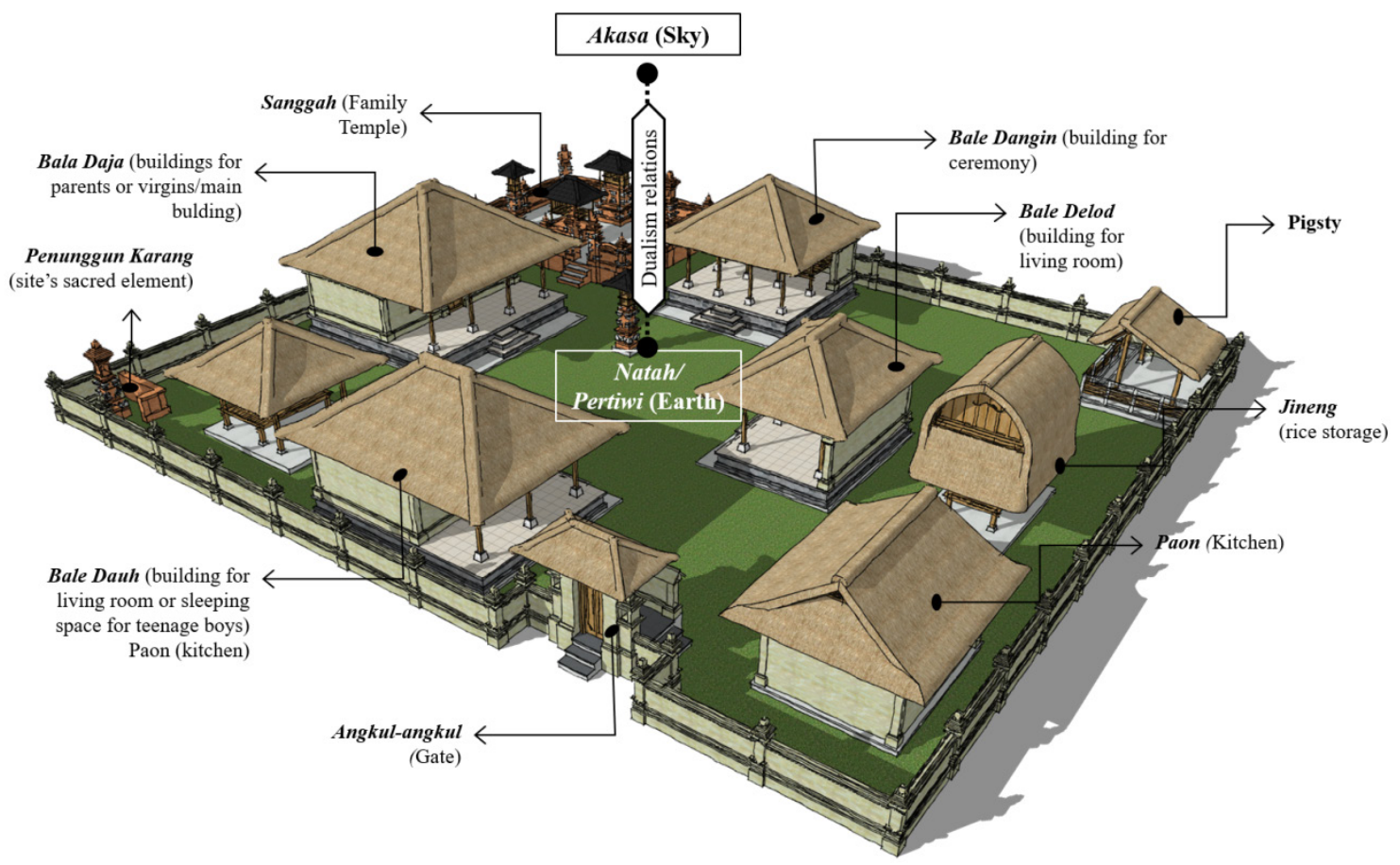

Figure 7. Dualism Pattern Relationship between Akasa and Pertiwi/Natah

\subsection{Synthesis: Universal Concepts and Local Concepts, Antithetic and Harmonious Dualism}

The Balinese ethnic community has a culture of living through a residential layout based on universal and local dualism patterns. The universal concept is usually the direction of the rising and setting of the sun. This polar dualism uses the sun to have a philosophical meaning as the source of life through the rays and light it produces. The sun does pair with the earth, which serves as a place for all living things to grow and thrive (world) (Paramadhyaksa, 2016). The sunrise and sunset direction are also the basis in Balinese ethnic living space, sunrise as a symbol of hope (soul) and sunset as a symbol of smelter (physical nature). In vernacular settlements in Indonesia, the territories that use the sun in their layout are the settlements of Dusun Segantar [29], Torajan residence [34], Kajang traditional residence [31], Singengu Village residence [32], and the residence of Kepencar Village [33]. In Bali, the direction of the sun's rising and the setting is a natural symbol in the placement of Bale Dangin and Bale Dauh. The sun's increasing focus has the meaning of the utama direction (sacred or high value). The sun's setting is nista (profane or low value) - the sun's philosophy's perspective and understanding influence Balinese ethnic residential buildings' layout in the lowlands. The local concept as the basis for the formation of Balinese ethnic residential architectural forms has different variants. The belief system of each resident influences this variant. Strong relationships with ancestors and place of origin are the direction of the primary residential orientation. The emotional connection between residents who occupy the house with the principle of orientation is believed to respect their ancestors. This local concept, as the direction of Kaja orientation, usually placed buildings that correlate with religiosity. This concept does use in forming a residential architectural layout for ethnic Balinese mountains and lowlands settlements.

The dualism pattern relationship in the architectural layout of the Balinese ethnic settlements has the meaning of dualism, antithesis, and harmony. The antithesis definition is that a high-value zone and low value mark the dualism pattern existence. Zones and directions that are of high value correlate with sacred, religious, and something glorified and respected; on the other hand, the value of the nista (low value) is in the form of a profane building a fusing and neutralizing role. During its development, spaces in the nista (low value) direction experienced more changes and additions to contemporary buildings than in the main path. Remain and changed becomes an antithesis or conflict between the two orientation poles in symbolic meaning and dynamic formation. In other perceptions, these two elements become harmonious concepts. Two parts mean that both strengthen in presenting a symbolically balanced space. This balance does achieve through ritual activities and roles, in which the two areas have their respective roles and have different rituals with the aim of spatial harmonization. So, that dualism pattern has an antithetic relationship from value and meaning and a harmonious relationship or mutually reinforcing each other's roles to create spatial balance. 


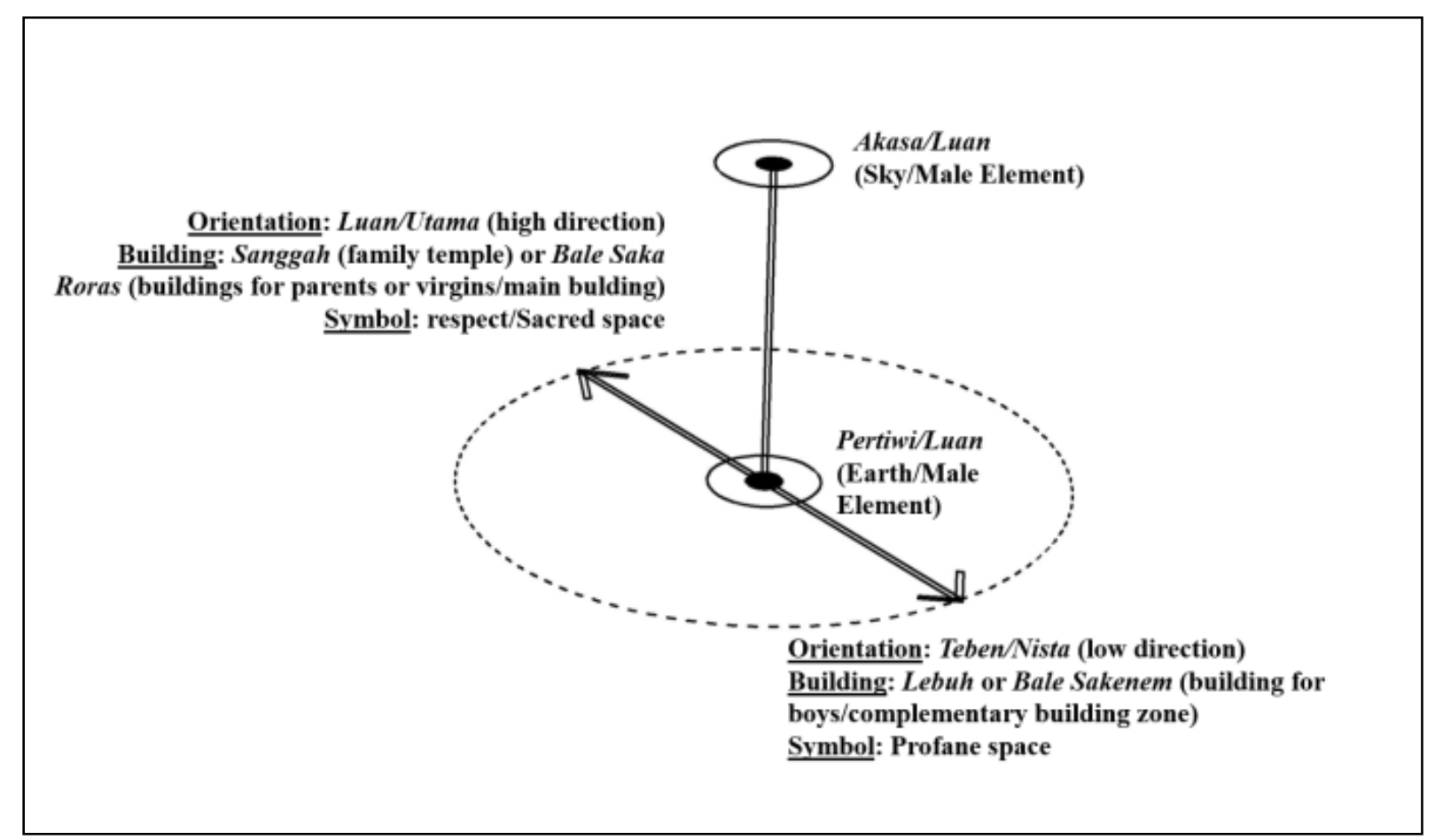

Figure 8. Dualism Pattern Concept in Highland Settlements

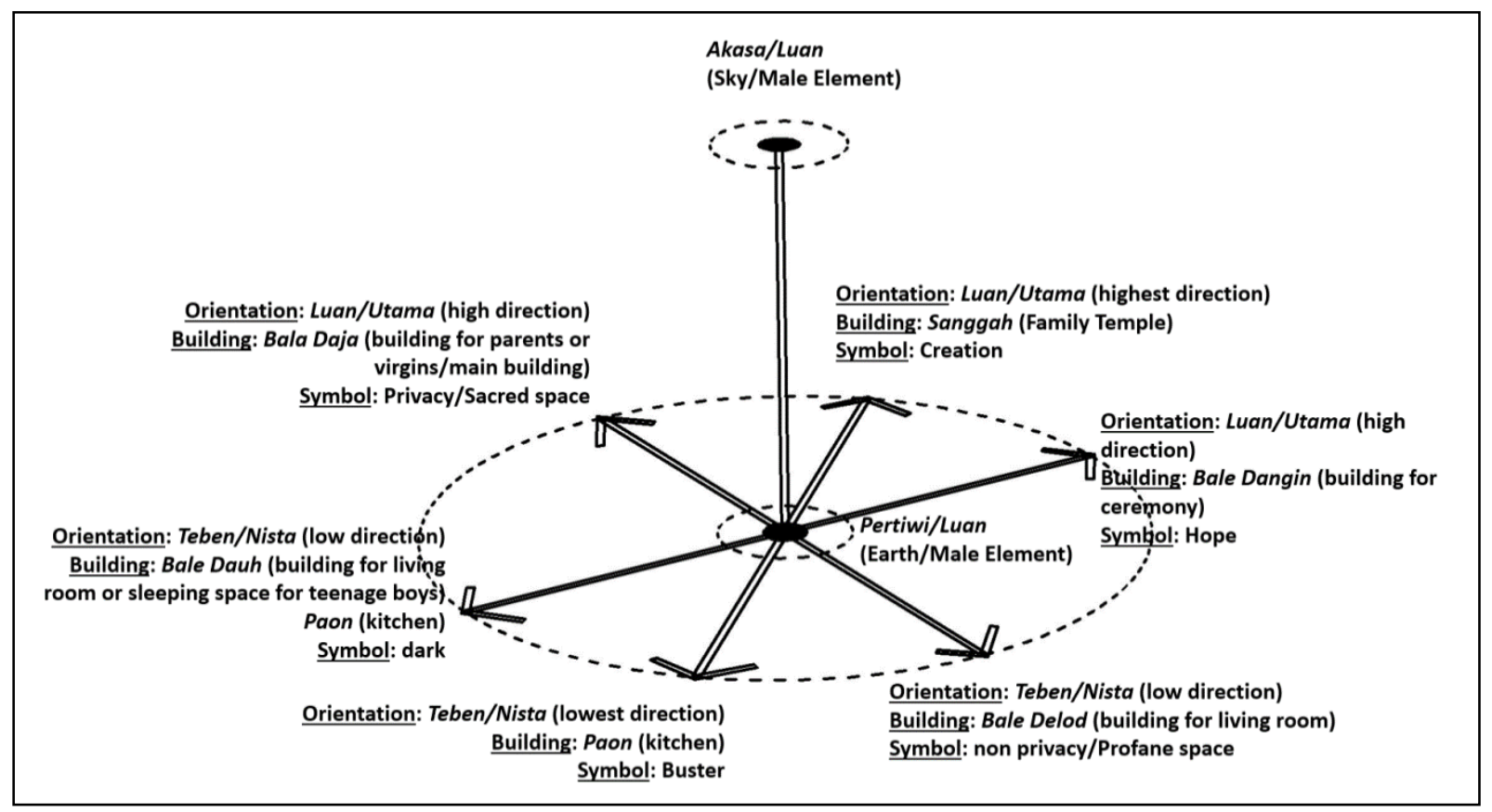

Figure 9. Dualism Pattern Concept in Lowland Settlements

\section{Conclusions}

Understanding the Balinese ethnic community in managing their residential space is based on a local and universal perspective that produces a dualism pattern. In the form of local and universal concepts, dualism pattern has their respective functions and roles and have their meaning and philosophy. The function aspect relates to each binary's space use divided into sacred or high value and profane or low value. The holy has a relationship with religiosity and privacy. The profane has a nonreligious and communal connection. The sacred concept relates to the meaning of the soul and the profane with a physical sense. Aspects of each pole's roles (high and low) have their respective roles and, of course, are different. However, it aims to create a harmonious relationship 
between the two aspects in carrying out its function. They do not cancel each other out but reinforce each other in creating a spatial balance (harmony). In the dynamics of the spatial development of ethnic Balinese residences, spaces that undergo changes and increase in building mass, namely areas with low value and buildings or architecture that have a relationship with religiosity and religion, do not experience significant changes. Antithesis and harmony as dualistic philosophies from dualism patterns are fundamental concepts in giving birth to the spatial idea of Balinese ethnic settlements in the high and low areas. Antithesis in spatial planning means different functions and roles, while harmony means strengthening each other's positions and roles in creating a harmonious and reinforcing relationship. This fundamental concept is the mindset or initial understanding of Balinese ethnic communities shaping and creating linear and nine spatial plans.

\section{Acknowledgments}

The research funds given by the Warmadewa University Research Institute to support this study are greatly appreciated. The architecture students from Warmadewa University for their assistance in gathering field data. Pinggan and Pengotan villages have graciously accepted our invitation to research their communities.

\section{REFERENCES}

[1] N. K. A. Dwijendra, Ancient Balinese Architecture \& Culture. Denpasar: Cooperation between CV. Bali Media Adhikarsa [and] Udayana University Press, 2009.

[2] N. K. A. Dwijendra, Traditional Balinese House Architecture. Denpasar: Udayana University Press, 2010.

[3] G. Tanuwidjaja, "Sustainable Architectural Design in Indonesia: My Green Home is My Green Country," Surabaya Arsit. Univ. Kristen Petra, 2011.

[4] I. M. J. Waisnawa, "Sanga mandala spatial pattern as an ecological concept in the arrangement of traditional Balinese houses," in Religion, Custom, Art, and History in Millennial Age, 2018, pp. 71-78.

[5] I. K. M. Wijaya, "Effect Local Direction on Balinese Traditional Settlement Layout, Case Study: Pengotan Traditional Village in Bali, Indonesia," Civil Engineering and Architecture, vol. 8, no. 6, pp. 1395-1407, 2020, DOI: $10.13189 /$ cea.2020.080622.

[6] I. G. N. T. Adiputra, N. Soewarno, and D. Wiyono, "Spatial Configuration of Pengotan Traditional Village - Bali," Media Tek., vol. 22, no. 2, pp. 3-13, 2000.

[7] I. N. W. Paramadhyaksa, N. K. A. Dwijendra, N. K. P. D. Jayanti, and I. K. M. Wijaya, "Implications Of Orientation Patterns On Spatial Planning In Pinggan Village, Bali
Indonesia," Solid State Technol., vol. 63, no. 6, 2020.

[8] I. K. M. Wijaya, "Study of Orientation of Kaja and Kangin Cosmology on Village Pinggan Settlement," in Exploring theVillage of Pinggan, Denpasar: Satria Aksara, 2019.

[9] A. Afandi, "Belief in Animism-Dynamism and Adaptation of Hindu-Buddhist Culture with Indigenous Culture on the Island of Lombok-NTB," Hist. | FKIP UMMat, vol. 1, no. 1, p. 1, Feb. 2018.

[10] R. Hasan, "Animist and Dynamism Beliefs in Aceh's Islamic Society,” MIQOT J. Ilmu-ilmu Keislam., vol. 36, no. 2, Dec. 2012.

[11] I. Ropi, Religion, and Regulation in Indonesia. Singapore: Springer Singapore, 2017.

[12] I. Malawi and F. Chasanatun, "The socio-cultural values of ' bersih desa ceremony': a cultural study at Simbatan Village, sub-district of Nguntoronadi, Magetan Regency, East Java," IOP Conf. Ser. Earth Environ. Sci., vol. 485, no. 1, p. 012107, Jun. 2020.

[13] L. Vinet and A. Zhedanov, "A 'missing' family of classical orthogonal polynomials," J. Phys. A Math. Theor., vol. 44, no. 8, p. 085201, Feb. 2011.

[14] N. K. A. Dwijendra, Traditional Balinese house architecture: based on asta kosala-kosali. Denpasar: Cooperation between Bali Media Adhikarsa [with] Udayana University Press, 2008.

[15] N. K. A. Dwijendra, "From tradition to modernization in morphological process of indigenous settlement patterns in Bali, Indonesia," Int. J. Adv. Sci. Technol., vol. 29, no. 8, pp. 856-868, 2020.

[16] H. S. Nordholt, "Custodians of the Sacred Mountains: Culture and Society in the Highlands of Bali," J. Soc. Issues Southeast Asia, vol. 19, no. 1, pp. SJ19-1h, Apr. 2004.

[17] A. W. Purwantiasning, "The Red Thread for the Establishment of Settlement Patterns and Occupancy Patterns in Bali Villages Begins to be Associated with Social, Economic and Cultural Aspects (Case Study: Pekraman Julah Village, Tejakula District, Bali)," J. Nalars, vol. 17, no. $1,2017$.

[18] T. A. Reuter, Custodians of The Sacred Mountains. Jakarta: Yayasan Obor Indonesia, 2005.

[19] T. A. Reuter, Our Ancestral House. Jakarta: Yayasan Pustaka Obor Indonesia, 2018.

[20] Sudiro, "Legend and Religion as National Integration Media," J. Hum., vol. 13, no. 1, 2001.

[21] I. K. M. Wijaya, "Conception of Natah and Lebuh as 'Space of Balance' in Traditional Balinese Architecture," J. Arsit. Zo., vol. 2, no. 2, 2019.

[22] M. Lullulangi, A. Tawani, and R. Rahmansah, "Architectural Typology of Mamasa Traditional Graves, West Sulawesi, Indonesia," Civil Engineering and Architecture, vol. 8, no. 5, pp. 832-837, 2020, DOI: 10.13189/cea.2020.080510.

[23] N. K. Agusintadewi, "Spatial Patterns of Traditional Bali Aga Settlements in Sekardadi Village, Kintamani," Rev. Urban. Archit. Stud., vol. 14, no. 2, pp. 47-57, Dec. 2016. 
[24] D. A. Amabi and T. K. Dima, "The Influence of Traditional Rituals on the Spatial Planning of the Traditional Settlement of the Matabesi Tribe in Belu Regency," Gewang Gerbang Wacana dan Ranc. Arsit., vol. 2, no. 1, pp. 9-15, 2020.

[25] R. Ch. Lake, "Traditional Spatial Architecture of the Atoni Tribe in Kampung Tamkesi, Timor Island," ATRIUM - J. Arsit., vol. 2, no. 1, 2016.

[26] Hamka, Antariksa, and L. D. Wulandari, "Characteristics of the Orientation of Bugis Traditional Houses (Bola Ugi) in Kajuara Hamlet, Bone Regency, South Sulawesi," LANGKAU BETANG J. Arsit., vol. 2, no. 2, Jul. 2015.

[27] I. Priyoga and M. M. Sudarwani, "Study of Space Patterns and Traditional Houses in Penglipuran Village, Bali," in Prosiding Seminar Peng-Konteks-an Arsitektur Nusantara, 2018, pp. A066-A072.

[28] Y. D. Purbadi, A. Djunaedi, and Sudaryono, "Kaenbaun wisdom as a conceptual basis for the spatial layout of the Dawan tribal settlement architecture in Kaenbaun desa village," ARTEKS J. Tek. Arsit., vol. 3, no. 2, 2019.

[29] Y. Rayson, A. M. Ridjal, and N. Suryasari, "The Role of Cosmology in the Formation of Settlement Spatial Patterns in Segenter Hamlet," J. Mhs. Jur. Arsit. Univ. Brawijaya, 2014.

[30] H. M. B., R. S. Rukayah, and S. R. Sari, "The settlement pattern of the Aboge community, Cikakak village, Wangon sub-district, Banyumas district," J. Arsit. Arcade, vol. 4, no. 2, 2020.

[31] E. Erawati, "Kajang Traditional Settlement Pattern," Kapata Arkeol., vol. 12, no. 2, p. 147, Dec. 2016.

[32] C. Nuraini, A. Djunaedi, Sudaryono, and T. Y. W. Subroto, "Bincar-Bonom as the basis of house formation in Singengu village settlement," J. Sci. Res. Stud., vol. 1, no. 4, 2014.

[33] V. G. S. Rejeki, N. Soewarno, S. Sudaryono, and T. Y. W. Subroto, "Cosmological Value in the Spatial Planning of the Settlement of Kapencar Village, Sindoro Mountain Slope, Wonosobo," Forum Tek., vol. 33, no. 3, 2010.

[34] Y. Sumalyo, "Cosmology in Toraja Architecture," Dimens. (Jurnal Tek. Arsitektur), vol. 29, no. 1, pp. 64-74, 2001.

[35] S. Ashdown, "The Paradox of Sacred and Profane Shared Space," J. Relig. Theol., vol. 3, no. 4, 2019.

[36] A. C. G. García and J. A. Belmonte, "Sacred Architecture Orientation Across The Mediterranean: A Comparative Statistical Analysis," Mediterr. Archaeol. Archaeon., vol. 14, no. 2, 2014.

[37] Z. Zhou, Z. Jia, N. Wang, and M. Fang, "Sustainable mountain village construction adapted to livelihood, topography, and hydrology: A case of Dong villages in Southeast Guizhou, China," Sustain., 2018.

[38] C. M. Giannantonio, "Content Analysis: An Introduction to Its Methodology (2nd ed.).," Organ. Res. Methods, vol. 13, no. 2, 2010.

[39] K. Krippendorff, "Reliability in Content Analysis.," Hum. Commun. Res., vol. 30, no. 3, pp. 411-433, Jul. 2004.

[40] A. B. Marvasti, "Qualitative content analysis: A novice's perspective," Forum Qual. Sozialforsch., vol. 20, no. 3,
2019.

[41] N. Muhadjir, Qualitative Research Methodology Edition IV, IV. Yogyakarta: Rake Sarasin, 2002.

[42] J. J. O. I. Ihalauw, Theory Construction: Components and Process. Jakarta: Grasindo, 2008.

[43] G. Arboleda, "Vernacular Architecture - Definition," What is Vernacular Architecture. 2011.

[44] S. Roaf, "Lessons from vernacular architecture," J. Archit. Conserv., vol. 20, no. 1, pp. 67-68, Jan. 2014.

[45] R. Waterson, The Living House: An Anthropology of Architecture in South-East Asia. Singapore/Oxford/New York: Oxford University Press, 1990.

[46] D. Whelan, "Built to meet needs: cultural issues in vernacular architecture - By Oliver, Paul," J. R. Anthropol. Inst., vol. 16, no. 1, pp. 165-166, Mar. 2010.

[47] T. Y. W. Subroto and A. S. Malangyudo, "The continuity of binary diametric space of Balinese house in Yogyakarta, Indonesia," City, Cult. Soc., vol. 5, no. 1, pp. 33-42, Mar. 2014.

[48] N. Rema, "Tradition of Ancestor Worship in Hindu Society in Bali," Forum Arkeol., vol. 27, no. 1, pp. 1-12, 2014.

[49] T. A. Reuter, The house of our ancestors : precedence and dualism in Highland Balinese society, no. 198. KITLV, 2002.

[50] I. G. M. Putra, "Changes in Expression of the Natah Concept in Spatial Planning in Bali," J. Permukim. Natah, vol. 1, no. 2, pp. 52-58, 2003.

[51] I. M. Suarya, "Natah's role in Balinese life," J. Permukim. "Natah," vol. 1, no. 1, 2003.

[52] I. N. W. Paramadhyaksa, "The Existence of Brahma Point in Traditional Balinese Spatial Planning," in Prosiding Seminar Nasional Tata Ruang dan SPACE\#2, 2015.

[53] I. K. M. Wijaya, "Discourse on the Concept of Balance of Sakala and Niskala Spaces in Ethnic Balinese Homes," in International Seminar Bali Hinduism, Tradition and Interreligious Studies, 2018, pp. 73-80.

[54] M. N. Indriani, The Existence of Balinese Hindu Local Wisdom in the Era of Globalization (Balinese Architecture and Subak Denpasar City). Denpasar: UNHI Press, 2018.

[55] I. A. D. Maharani, I. Santosa, P. Wardono, and W. Martokusumo, "Conservation of Bali Aga Residential Values (Ancient Bali) in Cultural Tourism in Penglipuran Village, Bangli," in Seminar Ikatan Peneliti Lingkungan Binaan Indonesia, 2017, pp. B193-B200.

[56] I. K. M. Wijaya, "The Sakala and Niskala Space Around the Banyan Tree in Denpasar," in Seminar Nasional Space \#3: Membingkai Multikultur dalam Kearifan Lokal Melalui Perencanaan Wilayah dan Kota, 2017.

[57] M. P. Karma and I. N. W. Paramadhyaksa, "Impact of Changes in Orientation Direction on Traditional Village Spatial Planning in Bali Case Study of Pupuan Village," in Prosiding Temu Ilmiah IPLBI 2018, 2018, pp. F057-F064.

[58] I. K. M. Wijaya, "The Local Wisdom Study of Luan And Teben Concept on Balinese Ethnic Houses," Local Wisdom J. 
Ilm. Kaji. Kearifan Lokal, vol. 12, no. 2, pp. 156-166, 2020.

[59] M. Eliade, The Sacred and The Profan. New York: Harcourt, Brace, and Word, Inc, 1957.

[60] M. Eliade, "Sacred Places: Temple, Palace, 'Centre of the World," in Patterns in Comparative Religion, 1958.

[61] B. Rennie, "Mircea Eliade: 'Secular mysticism' and the history of religions," Religion, vol. 38, no. 4, pp. 328-337,
Dec. 2008.

[62] I. K. M. Wijaya, "Ritual Spatial at Springs and Water Streams in Bali," in Civil Engineering and Material Technology Seminar (CEMTECS 2015), 2015.

[63] I. N. W. Paramadhyaksa, "Philosophy and Application of the Conception of the Padma Flower in the Embodiment of Traditional Balinese Architecture," LANGKAU BETANG J. Arsit., vol. 3, no. 1, Sep. 2016. 